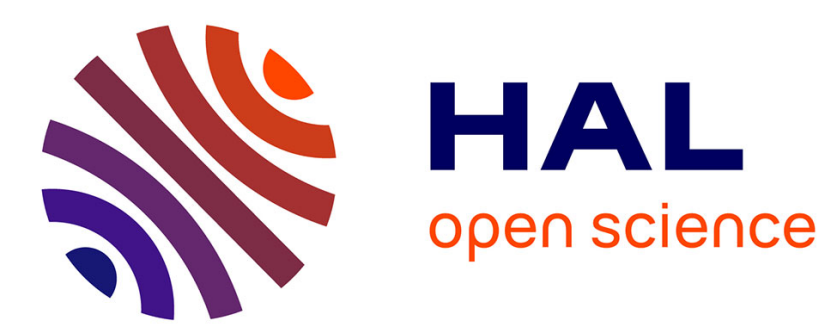

\title{
Is cold hardiness size-constrained? A comparative approach in land snails
}

Armelle Ansart, Annie Guiller, Olivier Moine, Marie-Claire Martin, Luc

Madec

\section{- To cite this version:}

Armelle Ansart, Annie Guiller, Olivier Moine, Marie-Claire Martin, Luc Madec. Is cold hardiness sizeconstrained? A comparative approach in land snails. Evolutionary Ecology, 2013, 28 (3), pp.471-493. 10.1007/s10682-013-9680-9 . hal-00909016

\section{HAL Id: hal-00909016}

\section{https://hal-univ-rennes1.archives-ouvertes.fr/hal-00909016}

Submitted on 25 Nov 2013

HAL is a multi-disciplinary open access archive for the deposit and dissemination of scientific research documents, whether they are published or not. The documents may come from teaching and research institutions in France or abroad, or from public or private research centers.
L'archive ouverte pluridisciplinaire HAL, est destinée au dépôt et à la diffusion de documents scientifiques de niveau recherche, publiés ou non, émanant des établissements d'enseignement et de recherche français ou étrangers, des laboratoires publics ou privés. 


\section{Is cold hardiness size-constrained?}

\section{A comparative approach in land s nails}

ANSART Armelle ${ }^{1 *}, \underline{\text { armelle.ansart@ univ-rennes1.fr }}$

$5 \quad$ GUILLER Annie ${ }^{2}$, annie.guiller@ univ-rennes1.fr

MOINE Olivier ${ }^{3}$, olivier.moine@cnrs-bellevue.fr

MARTIN Marie-Claire ${ }^{1}$, marie-claire.martin@ univ-rennes1

MADEC Luc ${ }^{1}$, luc.madec@ univ-rennes1.fr

10

${ }^{1}$ Université de Rennes 1, UMR 6553 Ecobio, bâtiment 14A, 263 Avenue du Général Leclerc, CS 74205, 35042 Rennes Cedex, France

${ }^{2}$ Université de Rennes 1, UMR 6553 Ecobio, Laboratoire de Parasitologie Pharmaceutique, 15 bâtiment 6, Avenue du Professeur Léon Bernard, 35043 Rennes Cedex, France

${ }^{3}$ Laboratoire de Géographie Physique, UMR CNRS 8591, 1 place Aristide Briand, 92195 MEUDON cedex, France

$20 *$ Corresponding author phone: (00 33) (0)2 23236865 fax: (00 33) (0)2 23235026 


\begin{abstract}
Body water is a major element of the cold-hardiness strategies observed in ectothermic animals, in particular in freezing avoidant species for which body ice formation is lethal.

5 Here, we investigate the relationships, in terrestrial snails, between the temperature of crystallisation (Tc) and body water (water mass and water content), shell shape, geographic and climatic distribution, taking into account phylogenetic inertia. Phylogenetic relationships among 31 species from 13 different families of terrestrial Gastropods were studied using 28S rRNA nuclear and COI mitochondrial sequence data, together with species-specific traits. Our

10 results provide evidence for clear relationships between Tc and absolute / relative body water: smaller species with lower water content tended to be characterized by colder temperatures of crystallisation, although some exceptions were noticeable. Environmental conditions do not appear to affect Tc significantly, as well as shell shape which is however correlated with water content. This study confirmed that supercooling ability in land snails is size-

15 cons trained, with consequences on cold-hardiness strategies.
\end{abstract}

\title{
Keywords
}

Terrestrial gastropods

20 Temperature of crystallisation

Body water

Phylogenetic relationships

\section{PGLS}




\section{Introduction}

Temperature is the main environmental factor acting on physiological processes, shaping the geographic distribution of living organisms. Because extre me cold conditions directly

5 threaten survival, one of the major goals of ectothermic species is to deal with minimal temperatures. Cold hardiness is thus a critical life history trait in the maintenance and development of a species in a cold-constrained habitat (Bale and Walters 2001; Moine et al 2002; Pither 2003; Bale and Hayward 2010; Chown et al 2010).

Cold hardiness is a widely studied aspect of ecophysiology, usually separating the species into two main categories: freezing avoidant and freezing tolerant species. What determines the cold tolerance strategy of a species is a combination of ecological (climate, microhabitat conditions; Kukal and Duman 1989; Costanzo et al 1998; Jing et Kang 2003), ontogenic (stage, mass; Vernon et al 1997; Grenot et al 2000; Jensen et al2007), and phylogenetic factors (Voituron et al 2009; Nyamukondiwa et al 2011).

15 For both strategies, the supercooling ability, i.e. the ability to maintain body fluids at a liquid state below the freezing point, is a critical parameter. Freezing tolerant organisms generally will have a poor ability to supercool, between -5 and $-10^{\circ} \mathrm{C}$ allowing slow freezing of tissues and thus sufficient time to implement protection mechanisms. On the contrary, in freezing avoidant organisms, for which ice formation in tissues is lethal, the supercooling ability will

20 be enhanced, often in association with the synthesis of large amount of antifreeze substances (for more information on these strategies, see for example Ramløv 2000; Zachariassen and Kristiansen 2000; Block 2003).

The temperature at which a water solution spontaneously freezes (i.e. the temperature of crystallisation, Tc) is determined by several factors: (i) the volume of the sample, the probability of nucleation being proportional to the number of water molecules (homogeneous 
nucleation), (ii) the presence of active ice nucleating agents (= INA; gut bacteria, proteins or lipoproteins), causing heterogeneous nucleation, (iii) the presence of antifreeze substances as polyols and sugars with colligative action or thermal hysteresis proteins.

The relationship between Tc and water volume has been known for a long time. Bigg (1953)

5 demonstrated that freezing temperature of pure water droplets is volume-dependent. Applied to animal ecology, this suggests that, in freezing avoidant species (i.e. in absence of active INA), a lower volume of body fluid is related to a more extended supercooling capacity (i.e. a lower Tc). This has been proved successfully at both intra-specific (David and Vannier 1996; Costanzo et al 1997; Ansart and Vernon 2004) and inter-specific levels (Lee and Costanzo 1998; Zachariassen et al 2004). However, these last findings should be taken with caution because the evolutionary history of the analyzed species was not taken into account. As demonstrated by Zachariassen et al (2004), the common idea that a larger volume of water also triggers a higher probability of heterogeneous nucleation has to be reconsidered: in their study, they showed that nucleation temperatures of freezing avoidant insect species were very close to that obtained from comparable pure water samples (Bigg curve, completed with data from MacKenzie 1977 and Wilson et al 2003), suggesting the absence of ice nucleating agents, even in the largest species.

Although they have not so far generated much interest in the cryobiologist community, terrestrial gastropods have a wide geographic distribution which justifies a thorough study of

20 their ability to survive cold conditions and of the associated mechanisms. Furthermore, a better understanding of their cold-hardiness is expected to improve palaeoenvironmental interpretations of Quaternary glacial species assemblages. In north-western and central Europe, among the 350 snail species described, 35 are present over the Arctic Circle (66 33'44") and 44 can be found at altitudes higher than $2000 \mathrm{~m}$ (Kerney et al 1983; Kerney and Cameron 1999). Related to their large habitat range is their ability to occupy buffered 
microsites during cold season and to endure long periods of inactivity (Storey and Storey 1990, 2004; Bailey and Lazaridou-Dimitriadou 1991; Pakay et al 2002).

Information on cold hardiness strategies is only available for a few species of terrestrial gastropods (eight species of snails and ten of slugs) and their mechanisms are still poorly

5 known (Storey et al 2007; Ansart et al 2010; Nicolai et al 2011; Slotsbo et al 2012; Koštál et al 2013). Although generalization is somewhat hazardous, smaller land snails (shell diameter up to $c a .15 \mathrm{~mm}$ ) are typically freezing avoidant, although no active synthesis of antifreeze substances has been detected. On the contrary, larger species are considered partially freezing tolerant, i.e. able to survive short duration of freezing of their body tissues (see Ansart and

10 Vernon 2003 for a review; Nicolai et al 2005). In the large snail Cornu aspersum, Ansart et al (2010) showed the presence of INA in the digestive tract, limiting the Tc of hibernating individuals. This coexistence of both strategies along a size gradient, which requires further confirmation, could reflect different advantages of each strategy as a function of the water volume, rather than an adaptation to environmental conditions. We hypothesize that, above a

15 certain size (i.e. a certain water volume), freezing a voidance is not a viable strategy, because too many cryoprotective molecules would be required to maintain the body fluid in a liquid state. According to such a model, we should observe a switch in the Tc of species along the size gradient: small, freezing avoidant species with a Tc following the Bigg curve prediction, and large, partially freezing tolerant species for which the Tc is not dependent on the water 20 volume.

The aim of this study is to determine which factors significantly influence the Tc of land snail species. We will consider both absolute and relative body water, i.e. water mass (WM) and water content (WC), which are both highly variable in land gas tropods. The shell shape, from depressed to globular, from oblong to conic, can also play a role in water relationships with the environment (Goodfriend 1986) and consequently in cold tolerance. Previous studies on 
Helix pomatia (Nicolai et al 2005) and Cornu aspersum (Ansart and Vernon 2004) showed significant Tc variations in snail populations living under different climates, but it was unclear if the se variations were related to different size and body water mass and/or to adaptation to prevailing climatic conditions.

5 In this work, we present original data corresponding to standardized experimental conditio ns and we investigate relationships between the temperature of crystallisation and environmental, physical and physiological factors in 31 land snail species, taking into account phylogenetic inertia. Using this approach, we are able to partition the relative impact of evolutionary $v s$. ecological pressures on a life history trait having a key-role in species

10 distribution.

\section{Material and methods}

Animals collection, identification and rea ring

Individuals of 31 land snail species from 13 families were collected during their activity period (spring and early autumn 2010 and 2011) in different localities and on various habitats (Fig. 1, Table 1). Taxonomic identification was based on the Kerney and Cameron (1999) field guide and recent faunas from Gargominy and Ripken (2011) and Gargominy and 20 Neubert (2011). For taxa particularly difficult to identify, we required help from Nicole Limondin-Lozouet (LGP, Meudon, France) and, for Clausiliids, from Olivier Gargominy (MNHN, Paris, France).

Species were all reared under standard ised activity conditions (Incubator AquaLytic 186-4; $20^{\circ} \mathrm{C}, 16 \mathrm{~h}: 8 \mathrm{~h}$ Light-Darkness photoperiod; ad lib food depending on species - cereal powder,

25 litter, moss, snail eggs; moist synthetic foam as substrate) until the beginning of the 
hibernation period (November). Over two weeks, they were gradually submitted to overwintering conditions $\left(5^{\circ} \mathrm{C}, 8: 16 \mathrm{LD}\right.$ photoperiod, neither food nor water provided), which were maintained constant for 4 months.

Water mass, water content and temperature of crystallisation

Measurements were performed only on adult snails. Individuals were rapidly weighed (Sartorius CP224S $\pm 0.1 \mathrm{mg}$ or Toledo XP2U $\pm 0.1 \mu \mathrm{g}$, depending on species) before being equipped for Tc determination. A thermocouple (Testo 177-T4, thermocouple type K) was

10 attached to each snail and animals were individually inserted into plastic tubes immersed in a cryostat (Huber Polystat CC3) filled with an antifreeze fluid maintained at $3^{\circ} \mathrm{C}$. The temperature of the bath was then cooled at the rate of $0.5^{\circ} \mathrm{C} \cdot \mathrm{min}^{-1}$. The exotherm recorded by the thermocouple indicated spontaneous freezing of the animal, with Tc being defined as the lowest temperature at the start of the exotherm.

15 As very small species may become active very rapidly when manipulated, samples were maintained on ice once out of the incubator. On average, 20 seconds were necessary to correctly attach each snail to the thermocouple. Individuals displaying any sign of activity were discarded and excluded from further analysis.

After Tc measurement, snails were dehydrated in a $60^{\circ} \mathrm{C}$ oven for two days and weighted 20 again to estimate their water mass (WM) and their water content (WC) expressed as WM divided by total mass. WM was log transformed to approach normal distribution. Depending on species, 5 to 30 individuals were retained for analyses. 


\section{Shell volume/surface ratio}

We estimated for each species the mean surface-volume ratio (S/V) of the shell. For 5 to 10 individuals of each species, we measured the shell height $(\mathrm{H})$, length (L), and width (W), as

5 defined by Kosnik et al (2006). Depending on the individual size, measurements were either performed using a calliper or a binocular microscope and image treatment system (Image J). Estimation of the volume and surface of a gastropod shell is not a trivial question (e.g. Raup and Graus 1972). Some authors, following the suggestion of Powell and Stanton (1985), consider the formula for a cone as a good estimation of shell volume. However, this is based on only 3 globular marine species (Thais haemastoma, Polinices duplicatus, Littorina ziczac). To better approximate the shell volume, we directly estimated it for 8 of the biggest species (Co, Em, Ev, Hla, Ma, Pe, Tp, Zd) by weighing the volume of water displaced by the shell (with obstructed aperture) when placed in an hermetically closed recipient (Örstan 2011). The measurement was repeated for 10 individuals of each species. We then compared the volume

15 obtained with those calculated with the formula of a cone and of an ellipsoid. In all cases, the best approximation was the arithmetic mean between the volume of a cone and the volume of an ellipsoid. Between both methods, direct measurement and calculation, we found a mean difference inferior to $7 \%$ (maximal difference: $13 \%$ ) and a minimal correlation coefficient of $0.91(\mathrm{p}<0.001)$. Volume calculation could then be extrapolated to small species for which

20 direct measurement is not possible.

The shell surface was evaluated as the arithmetic mean between the surface of a cone and the surface of an ellipsoid. The formula for the surface of an ellipsoid, being in reality of a high complexity, was approached thanks to the Knud Thomsen's formula: $\mathrm{S}_{\text {ellip }}=$ $4 \pi\left[\left(\mathrm{H}^{\mathrm{p}} \mathrm{L}^{\mathrm{p}}+\mathrm{H}^{\mathrm{p}} \mathrm{W}^{\mathrm{p}}+\mathrm{L}^{\mathrm{p}} \mathrm{W}^{\mathrm{p}}\right) / 3\right]^{1 / \mathrm{p}}$, where $\mathrm{p}=1.6075$ (Klamkin 1971, 1976). The surface of a cone follows: $\mathrm{S}_{\text {cone }}=\pi(\mathrm{L} / 2)^{2}+\left[\pi \mathrm{L} / 2 \cdot \sqrt{ }\left((\mathrm{L} / 2)^{2}+\mathrm{H}^{2}\right)\right]$. 
As $\mathrm{S} / \mathrm{V}$ is highly related to the animal size, we used a corrected $\mathrm{S} / \mathrm{V}, \mathrm{SV}_{\text {corr }}=\mathrm{S} / \mathrm{V} .(\mathrm{H}+\mathrm{L}+\mathrm{W}) / 3$, allowing to consider varying shapes for comparable sizes.

\section{Geographic and climatic data}

The distribution ranges of the different species were obtained from maps published in Kerney et al (1983) and completed in Kerney and Cameron (1999). The north-west European geographic area covered by this guide excludes Iberian Peninsula and Italia and extends eastward to include Hungary, Slovakia, Poland and Finland (Fig. 1). Distribution areas were ArcInfo v.10.0. We extracted for each species the surface of the area occupied (with an error estimated at less then $3 \%$ ), the minimal and maximal latitude and the minimal and maximal longitude $\left( \pm 0.5^{\circ}\right)$. Surface data were log-transformed prior to analyses.

For two species, for which maps were not available (Cantareus apertus and Helix lucorum)

15 we compiled data from INPN (http://inpn.mnhn.fr/) and Fauna Europaea (http://www.faunaeur.org), completed with personal observations.

We also compiled data on maximal altitude reached by species available on AnimalBase website (http://www.animalbase.uni-goettingen.de/).

Climatic data were obtained from the ECA\&D website (European Climate Assessment \&

20 Dataset, http://eca.knmi.nl/; Klein Tank et al 2002). ECA\&D provides freely available climatic information, compiling daily measurements over the 30 last years from 6596 meteorological stations throughout Europe and Mediterranean. We first recorded for each species 25 climatic indices (temperatures and cold indices). Extreme values of each index were retained only if they concerned at least $5 \%$ of the species distribution range. 
Climatic and geographic informations were summarized by their factorial scores in a Principal Component Analysis, using the FactoMineR package in the R software (Lê et al 2008; Fig. 2). We retained the most pertinent variables (10 climatic indices and 6 geographic variables) based on their contribution to the variance of significant axes. The first one accounted for

$5 \quad 71.9 \%$ of the total inertia and opposed at the left side Mediterranean and Atlantic species, with reduced distribution area and mild climate to ubiquitous and northern species at the right side. The second axis was less informative (13.6\% of total variation): two variables, minimal latitude and minimal longitude, had an important contribution to its total variance (respectively $38.6 \%$ and $23.9 \%$ ), separating species which were not found on western or

10 southern limit of the study area $(\mathrm{Col}, \mathrm{Pa}, \mathrm{Cc})$ from the others. Species coordinates on the first axis were then used as a measure of their environmental conditions (ENV) and introduced in subsequent analyses. We also considered the minimal value of the mean daily temperature in December-January-February over the distribution range of each species for the last 30 years $\left(\mathrm{ENV}_{\min }\right)$ and the mean winter temperature at the collection site $\left(\mathrm{ENV}_{\text {loc }}\right) . \mathrm{ENV}_{\text {loc }}$ was

15 determined using data from the nearest MeteoFrance station, except for Helix pomatia collected in Germany and for which we considered data from the nearest ECA\&D station; these data were available for various duration, from 2 to 20 years.

\section{Molecular data and tree construction}

\section{DNA extraction, amplification and sequencing}

The protocol followed here has been described in Guiller et al (2001). Briefly, total genomic DNA was obtained from fresh material and genomic DNA was extracted using the chelex extraction protocol (Estoup et al 1996). We amplified fragments of approximately 433bp and $686 \mathrm{bp}$ for the 28S rRNA nuclear and COI mitochondrial genes respectively. The 28S (LSU) 
fragment was amplified using primers 28SF (5'-AACGCAAATGGCGGCCTCGG-3') and 28SR (5'-AAGACGGGTCGGGTGGAATG-3') (Koene and Schulenburg, 2005). The COI region was amplified using FCOI (5'-ACTCAACGAATCATAAAGATATTGG -3') and RCOI (5'-TATACTTCAGGATGA

5 CCAAAAAATCA-3') primers (Folmer et al 1994). Amplification of template DN A was carried out in $15 \mu \mathrm{l}$ volumes with MyTaq Mix (2X) (Bioline, France), $0.20 \mu \mathrm{m}$ each primer and 1.5 $\mu$ l DNA (approx. 50ng). The PCR conditions were for $28 \mathrm{~S}$ rRNA, 5 min at $95^{\circ} \mathrm{C}$, followed by 35 cycles of $95^{\circ} \mathrm{C}(20 \mathrm{~s}), 62.5^{\circ} \mathrm{C}(30 \mathrm{~s}), 72^{\circ} \mathrm{C}(1 \mathrm{~min})$ and a final extension phase at $72^{\circ} \mathrm{C}$ for $10 \mathrm{~min}$; for COI, an initial denaturation step of $94^{\circ} \mathrm{C}(5 \mathrm{~min})$, followed by 35 cycles of $94^{\circ} \mathrm{C}(45 \mathrm{~s}), 52^{\circ} \mathrm{C}(45 \mathrm{~s}), 72^{\circ} \mathrm{C}(1 \mathrm{~min})$ and a final extension phase at $72^{\circ} \mathrm{C}$ for $7 \mathrm{~min}$. Amplification products were checked using $2 \%$ agarose gel stained with ethidium bromide. Double-strand sequences were obtained using an automated sequencer (Plate-forme de séquençage et génotypage OUEST-genopole ${ }^{\circledR}$ ). We used sequences from the GenBank for Pomatias elegans (28S, accession $n^{\circ}$ AY014161) and the outgroup Gibbula umbilicalis (28S, JN686190 and COI, JN686278).

\section{Sequence analysis}

Mitochondrial sequences were aligned using the built-in assembly algorithm of the CodonCode Aligner software (v3.5, CodonCode Corporation, Dedham, Massachusetts). For $28 \mathrm{~S}$ rRNA gene, we manually adjusted the region based on the 28 rRNA sequence alignment of Euthyneuran gastropods published in Dayrat et al (2001). We removed a set of 212 sites (between the 426 th to the $637^{\text {th }}$ position) because the alignment was too ambiguous in that region. For the COI gene, we excluded the variable third codon position from the analysis to reduce the homoplastic effect of transitions on tree reconstruction, especially at 
higher levels of divergence. New sequences produced for $28 \mathrm{~S}$ and COI genes were submitted to GenBank (Table 2).

\section{$\underline{\text { Phylogenetic analysis }}$}

Phylogenetic relationships among individuals of different species were investigated using bayesian-based inference (BI) and maximum likelihood (ML) methods. The best fit model of nucleotide substitutions was selected prior to BI and ML analyses using the Akaike Information Criterion (AIC). The software MrAIC v1.4.2 (Nylander 2004) was used to

5 evaluate the fit of the data to 24 different models of nucleotide substitutions. The resulting best fit models were $\mathrm{GTR}+\mathrm{G}$ and $\mathrm{GTR}+\Gamma+\mathrm{G}$ for $28 \mathrm{~S}$ and $\mathrm{COI}$ genes respectively (general time-reversible with six different rates for transitions and trans versions, unequal base frequencies, a gamma distribution parameter $\Gamma$ that describes rate variation across variable sites and a parameter $I$ for invariable sites). Each model of nucleotide substitution was

10 incorporated in MRBAYES v3.1.1-p1 (Ronquist and Huelsenbeck 2003) and in PHYML V2.4.4 (Guindon and Gascue12003) for BI and ML analyses respectively. For ML analysis, the robustness of inferences was assessed by bootstrap resampling using 1000 repetitions. For Bayesian analyses, the posterior probabilities of trees and parameters were approximated with Markov Chain Monte Carlo (MCMC) and Metropolis coupling.

15 Single-gene analyses provided trees with good resolution but to improve the accuracy of phylogenetic inference and avoid topological variation found among trees constructed from each single gene, we analyzed genes simultaneously in concatenated $28 \mathrm{~S}$ and COI sequences into a super-gene alignment of $881 \mathrm{bp}$. For BI analysis, we ran two independent MCMC analyses with four chains each and a temperature set to 0.2 . Each chain was run for 10,000,000 cycles with trees sampled every 100 generations. Posterior probabilities were obtained from the $50 \%$ majority rules consensus of trees sampled after discarding the trees 
saved before chains reached apparent stationarity (i.e. a 'burn-in period' of 8,000 generations for both concatenated). The average standard deviation of split frequencies after 10,000,000 generations was below $0.01(0.004423)$, indicating a very good convergence between the two runs.

\section{Statistical analyses}

All analyses were implemented in the R software, v.2.14.0., using the Geiger (Harmon et al 2008), Caper (Orme et al 2012) and MuMIn (Bartoň 2009) packages.

10 Studying the relationships between traits needs to take into account the more or less common evolutionary history of species, i.e. the non-independence of data. Prior to conduct a phylogenetic comparative analysis (PCA), it is necessary to control for phylogenetic signal in data, unless classical cross-species statistics have to be applied. Another prerequisite to PCA is to control for the model of evolution of the data (Freckleton 2009).

15 As recommended by Revell (2010), we estimated for each variable and for each simple or multiple linear regression model, the Pagel's maximum likelihood $\lambda$ which, scaling the internal branches of the tree, allows to have an estimation of the phylogenetic signal in dataset $(0=$ independence of data, i.e. "star" like tree; $1=$ Brownian Motion $(\mathrm{BM}) ; 0<\lambda<1=$ phylogenetic signal with an evolution model different of BM). Likelihood ratio tests permit to compare the calculated $\lambda$ with the values 0 and 1 (Pagel 1999; Freckleton et al 2002). When adapted, the best evolution model was researched, based on the AIC value and comparison of likelihood with chi square tests (Nunn 2011).

Multiple phylogenetic correlations between explicative variables $\left(\log \mathrm{WM}, \mathrm{WC}, \mathrm{SV}_{\text {corr }}, \mathrm{ENV}\right.$ variables) were tested with the Bonferroni correction for $\mathrm{p}$. 
To determine which factors explain changes in the mean Tc of species, we built linear models. Eight models (including complete model, K from 1 to 4 ) relating variables to Tc were examined, taking into account phylogenetic relationships between the 31 species. Models fit was estimated by corrected $\mathrm{AIC}\left(\mathrm{AIC}_{\mathrm{c}}\right)$, the models with the minus $\mathrm{AIC}_{\mathrm{c}}$ and summing more

5 than $90 \%$ of weights (i.e. relative fits) being retained.

\section{Results}

$W M, W C, T c, S V_{c o r r}($ Table 2)

The mean fresh mass of tested species ranged from $1.4 \mathrm{mg}$ for Columella edentula to $33.5 \mathrm{~g}$ for Helix lucorum, corresponding to a WM of $0.6 \mathrm{mg}$ and $22.1 \mathrm{~g}$ respectively, i.e. a variation factor of approximately 37,000 between the two extremes. Species WM appeared to be an excellent estimator of the total fresh mass and of the shell volume (PGLS, log-log

15 correlations, $r>0.99$ and $p<0.001$ ). The WC varied between $28.45 \mathrm{gH}_{2} \mathrm{O} . \mathrm{gFM}^{-1}$ for Clausilia bidentata and $68.77 \mathrm{gH}_{2} \mathrm{O} \cdot \mathrm{gFM}^{-1}$ for Cantareus apertus.

The minimal Tc was obtained for C. edentula with a mean of $-16.8^{\circ} \mathrm{C}$ and the maximal for $H$. lucorum with $-4.5^{\circ} \mathrm{C}$.

$\mathrm{SV}_{\text {corr }}$ was maximal for oblong and depressed shells and was minimal for conical and globular 20 ones, varying between 7.5 and 11.1 .

\section{Environmental data}

As the variables $\mathrm{ENV}_{\text {min }}$ and $\mathrm{ENV}_{\text {loc }}$ were correlated with ENV (PGLS, respectively r=0.97, $\mathrm{p}<0.001$ and $\mathrm{r}=0.54, \mathrm{p}<0.001)$ and led exactly to the same conclusions, we considered only 
ENV in subsequent analyses. In the geographic limits of this study, Ciliella ciliata has the smallest range, with an area of ca. 27,500 km²; Nesovitrea hammonis and Cochlicopa lubrica could be found in the whole geographic area covered by this guide, except the centre of Iceland, with a distribution area of 3.37 million $\mathrm{km}^{2}$. Nine species were registered at altitudes

5 above $2500 \mathrm{~m}$ (Aa, As; Cl, Cs, Em, Hli, Pa, Vc, Zd). The minimum daily temperature endured by the snails varied from $-7.5^{\circ} \mathrm{C}$ for Mediterranean and Western littoral species $(\mathrm{Co}, \mathrm{Ev}, \mathrm{Ca})$, with less than 70 of frost days per year, to $-32.5^{\circ} \mathrm{C}$ for ubiquitous and Northern ones (11 species), with up to 220 frost days per year.

The topology of the BI and ML trees based on combined 28S and COI sequences were consistently similar. However, since bootstrap values did not strongly support ML tree, we considered and showed the BI tree based on combined 28S and COI genes. The corresponding topology showed a first genetic gap between the Caenogastropoda Pomatias elegans and all the other species, belonging to the Heterobranchia clade. A second genetic gap separated both Vertiginidae from other Stylommatophoran species, splitted into clades A and B (Fig. 3). The A clade, including only Sigmurethra species, differentiated the Clausiliidae from the Helicoidea, strongly supporting the monophyly of Helicidae and Hygromiidae s.l.

20 However, the tree resolution did not allow to totally resolve phylogenetic relationships among Helicidae and polytomies appeared. The B clade consisted of both Sigmurethra and Orthurethra taxa and included families that were well supported (Oxychilidae,, Pupillidae and Enidae). The lack of monophyly of the Orthurethra was due to the position of Vertiginidae and Oxychilidae, which were however well supported (credibility value of respectively $100 \%$ and $85 \%$ ). 
Phylogenetic signal and mode of evolution

5 For the variables $\mathrm{Tc}, \log \mathrm{WM}, \mathrm{WC}$ and $\mathrm{SV}_{\text {corr, }}$, the Pagel's $\lambda$ ranged from 0.96 to 1 ; it was significantly different from 0 , indicating phylogenetic signal for data and did not significantly deviate from 1 , indicating a BM model of evolution. For ENV, $\lambda$ was equal to 0.785 and was neither different from 0 , nor from, precluding any statement.

Evolution models incorporating $\lambda$ scaling always fitted better to the data than simple $\mathrm{BM}\left(\chi^{2}\right.$, $p<0.005$, between log likelihood obtained for both models). To deal with polytomies in the tree topology, we performed PGLS method (Grafen 1989) to analyse dataset. Diagnostic tools revealed no trend between residual values and fitted values and no outlier, demonstrating their adequate application.

\section{Correlations between variables and model selection}

Taking into account phylogenetic relationships between species, the correlation between variables $\operatorname{logWM}$ and $\mathrm{WC}$ was not significant. However, as $p$ was near the significance threshold ( $p=0.015$ for $\alpha=0.0083$ ) and as both variables are partially redundant, we performed

20 subsequent analyses with the residuals values of the cross-species regression $\mathrm{WC}=\mathrm{f}(\operatorname{logWM})$ $\left(r^{2}=0.36, \mathrm{df}=29, p<0.001\right)$, called $\mathrm{WC}_{\mathrm{res}}$ and ranging from -18.51 to $11.77 \mathrm{gH}_{2} \mathrm{O} \cdot \mathrm{gFM}^{-1}$. The only significant phylogenetically-corrected correlation was between $\mathrm{WC}_{\text {res }}$ and $\mathrm{SV}_{\text {corr }}$ (Table 3). Land snails with oblong or depressed shell (i.e. with the highest $\mathrm{SV}_{\text {corr }}$ ) had the lowest $\mathrm{WC}_{\text {res }}$ in opposition to species with globular shell (Fig. 4). 
The best-fit models, i.e. with the lowest $\mathrm{AIC}_{\mathrm{c}}$ and cumulated weight of $93.7 \%$ (Table 4), took into account $\log \mathrm{WM}$ and $\mathrm{WC}_{\mathrm{res}}$, which were the only significant predictors of the mean $\mathrm{Tc}$ (Fig. 5). ENV and $\mathrm{SV}_{\text {corr }}$ did not contribute to Tc variation. LogWM and $\mathrm{WC}_{\text {res }}$ explained as much as ca. $57 \%$ of the total variance of Tc, the contribution of logWM (estimated

5 coefficients) being always higher than that of $\mathrm{WC}_{\text {res }}$.

Tc values predicted by $\log \mathrm{WM}$ and $\mathrm{WC}_{\text {res }}$ variations (slope coefficients considered were arithmetic means of those of retained models) were compared with observed values (Fig. 5): nine of the 31 species had a Tc differing less than two degrees of what was expected from models and 10 were between two and three degrees. For only two species (Pe, Nh), the

10 observed Tc were more than two degrees higher than expected values, whereas three (Aa, Cs, Hla) had a Tc more than six degrees below that expected.

\section{Discussion}

15 One frequent weakness of comparative analyses compiling large datasets is that they rely on bibliographic sources that often involve missing values, various ways of data collection and precision, as well as uncertain phylogeny (Freckleton 2009). The main limit of studies based on complete experimental data is the low number of species included into the analysis, generally under 30 (see for example: Cruz et al 2001 - 19 species; Moran 2004 - 17 species;

20 Nyamukondiwa et al 2011 - 18 species; Strachan et al 2011 - 25 species; Anker and Baeza 2012 - 18 species). A noticeable exception is the recent work of Kellermann et al (2012) reporting data on desiccation and cold resistance for more than 90 Drosophila species, in relation with their geographic distribution. This thorough analys is revealed a moderate-tostrong phylogenetic inertia for cold resistance traits. Here, we were able to obtain complete 
data for 31 land snail species, a number sufficient to detect phylogenetic dependence of data when present (Freckleton et al 2002; Blomberg et al 2003).

We were indeed able to detect a strong phylogenetic signal for physical and physiological variables, which are known to be largely conserved through evolution, in contrast to

5 environmental data, for which it was not possible to determine phylogenetic dependence or independence (Blomberg et al 2003).

Phylogenetic multiple regressions showed that the water mass and the water content were both independent predictors of the mean temperature of crystallisation of snail species during hibernation, explaining together at least $55 \%$ of the variation, whereas no effect of environmental variables and of shell shape was detected. Strachan et al (2011) established a relationship between the water mass and the supercooling ability of first larval instars of freezing intolerant Drosophila species, but they did not detect any phylogenetic signal. Nevertheless, it is worth noting that their study was conducted on a single genus, with a variation of the mean fresh mass and of Tc of respectively $c a . \times 200$ and $\times 2$. Our study considered 13 families from different clades, with a very important variation factor in fresh mass $(c a . \times 37,000)$ and a variation factor of Tc of only $c a . \times 4$, that could highlight the necessity to consider a large range of variation in studied traits for such experiments. Even if no ENV effect appeared in analyses, our study does not allow to conclude to the absence of adaptive strategy in cold hardiness under different climatic conditions. At a larger

20 scale (366 species of north-west European land snails), Hausdorf (2003) observed a decrease of body size with latitude, but this effect disappeared when phylogenetic relationships were taken into account, as it was mainly due to the predominance of small bodied clades at higher latitudes and some large bodied clades as Helicoidea at lower latitudes. This would lead to conclude that the phylogenetic constraint on the body size, i.e. on the water volume, is the main factor of species distribution and can be related to their supercooling ability. Thus, only 
the smallest species with low Tc could persist in the coldest areas. Further investigations on species cold-hardiness are needed to test this hypothesis, as well as more precise data on conditions prevailing in overwintering microsites.

The snail shell shape is the result of many contradictory or overlapping causes with no clear

5 pattern. In particular, relationships between environmental conditions, as climatic ones, and height, whorl number or aperture size are poorly understood (Goodfriend 1986). To Goodfriend (1983), more elongated shells with smaller aperture would allow snails to retract more deeply and would limit water loss during inactive period. On the contrary, Machin (1967) showed that a significant water loss occurred through the shell in dormant snails,

10 animals with a high surface-volume ratio shell being more sensitive to desiccation. In this study, $\mathrm{SV}_{\text {corr }}$, reflecting the shell shape, had no effect on $\mathrm{Tc}$, but we found a significant (phylogenetically-corrected) correlation between the water content of hibernating snails and their $\mathrm{SV}_{\text {corr. }}$ Snails with globular shells had a higher water content during overwintering than oblong, conical or depressed ones, what would support Machin's hypothesis (1967). Globular

15 shells would be beneficial to face dehydration in high temperature conditions but could not contribute to decrease the Tc in winter conditions. As globular shells are mainly found in one of the considered clades (Helicoidea), which also contains the biggest species, it remains difficult to disentangle the different effects.

We hypothesized that small land snail species would have a low Tc depending on the body

20 water volume, no INA being active, and that large species would exhibit poor supercooling ability independently of water mass and content variations (Ansart and Vernon 2003; Nicolai et al 2005). However, we did not detect any switch in Tc values depending on species size, but a linear regression between Tc and body fluid variables. Moreover, it is worth noting that in our models, the mean estimated coefficient for logWM predictor (2.62) is not significantly 25 different of that of the Bigg curve, predicting the Tc as a function of pure water mass 
variation $(\mathrm{Tc}=2.25 \log \mathrm{WM}-24$; slope comparison: $\mathrm{ANOVA}$, interaction term, $\mathrm{F}=3.50$, $\mathrm{p}=0.07$; see Zachariassen et al 2000). Our results also demonstrate the necessity to take into account the hydration state of tissues in predictions, as it reflects the amount of freezable water. Only two species had a high Tc considering their size: the Oxychilidae Nesovitrea

5 hammonis and the Pomatiidae Pomatias elegans. The first remained active for several weeks before ceasing activity when placed under hibernation condition, probably retaining more INA than species being dormant for a longer time; the second is a Caenogastropoda, some intertidal close-related species having some freezing tolerance level (Sinclair et al 2004). Although no outlier was found in the selected predicting models, some Tc observations were significantly lower than values predicted from multiple regressions, with differences reaching ca. 7 degrees for Arianta arbustorum and 6 degrees for Helicigona lapicida and Cepaea sylvatica. All three species are Helicidae (i.e. large snails) which can be encountered at high altitude (above $2000 \mathrm{~m}$ ) and also at high latitude for $A$. arbustorum. Such finding suggests the existence of adaptive mechanisms in these species, as synthesis of cryoprotectants, and would

15 deserve further investigations. Our study did not allow to determine the presence of INA in large snail species contrary to small species, as we hypothesized, but it also does not prove their absence as their action can be masked by body fluid parameters: for such species, it could be useless to eliminate or inactivate such INA during cold periods.

20 This study aimed to address the two following questions: does the temperature of crystallisation of a species depend on its size, i.e. its body water, and are nucleating agents more active in large species? Although experimental approach is a way to guarantee data consistency, it can force the expression of studied traits. The necessity of rearing animals for several months in standardised conditions can also introduce a bias in the sampled species,

25 since some species did not survive laboratory conditions. 
In spite of these caveats, results are consistent with the hypothesis that Tc is size-constrained in land snails, large species with high water mass and water content exhibiting a lower ability to supercool. Although we were not able to detect the presence of active INA in large species, our observations suggest freezing avoidance to be more common in small species (as

5 confirmed by existing studies and particularly the recent work of Koštál et al 2013); in the majority of large snail species, Tc depends on body fluid parameters, making the freezing avoidance strategy more difficult to adopt and leading to partial freezing tolerance as shown in Helix pomatia and Cornu aspersum (Nicolai et al 2005; Ansart et al 2001). This work confirms the strong impact of evolutionary pressures on life-history traits as cold hardiness in ectotherms.

\section{Ackno wledge ments}

We are thankful to Nicole Limondin-Lozouet and Olivier Gargominy for their help in species

15 identification, to Yann Rantier for extraction of geographic information on species, to Philippe Vernon and anonymous referees for constructive comments and to all the people who collected snails for this study purpose, in particular Annegret Nicolai, Mathieu Daëron and Thomas Geslin. This work benefited from the ATBI (All Taxa Biodiversity Inventory) Mercantour program and was partly supported by MAPGEO project, funded by the INSU/INEE PALEO2 program of Centre National de la Recherche Scientifique (CNRS). 


\section{References}

Anker A, Baeza J.A (2012) Molecular and morphological phylogeny of hooded shrimps, genera Betaeus and Betaeopsis (Decapoda, Alpheidae): testing the center of origin biogeographic model and evolution of life history traits. Mol Phylogenet Evol 64:401415

Ansart A, Nicolai A, Vernon P et al(2010) Do ice nucleating agents limit the supercooling ability of the land snail Cornu aspersum? Cryoletters 31:329-340

Ansart A, Vernon P (2003) Cold hardiness in Molluscs. Acta Oecol 24:95-102

10 Ansart A, Vernon P (2004) Cold hardiness abilities vary with the size of the land snail Cornu aspersum. Comp Biochem Physiol A 139:205-211

Ansart A, Vernon P, Daguzan J (2001) Photoperiod is the main cue that triggers supercooling ability in the land snail, Helix aspersa (Gastropoda: Helicidae). Cryobiology 42:266273

15 Bailey SER, Lazaridou-Dimitriadou M (1991) Inverse temperature acclimation of heart rate in hibernating land snails. J Comp Physiol B 160:677-681

Bale JS, Hayward SAL (2010) Insect overwintering in a changing climate. J Exp Biol 213:980-994.

Bale JS, Walters KFA (2001) Overwintering biology as a guide to the establishment potential of non-native arthropods in the UK. In: Atkinson D and Thornd yke M (eds.) Environment and animal development: genes, life histories and plasticity. BIOS Scientific Publishers Ltd, Oxford, pp. 343-354 
Barker GM (2001) Gastropods on land: phylogeny, diversity and adaptive morphology. In:

Barker GM (ed.) The biology of terrestrial molluscs. CABI Publishing, Wallingford, pp. $1-146$

Bartoň K (2009) MuMIn: multi-model inference. Available from http://r-forge.rproject.org/projects/mumin/ (accessed April 2013)

Bigg EK (1953) The supercooling of water. Proc Phys Soc Lond. B 66:688-694

Block W (2003) Water or ice? - the challenge for invertebrate cold survival. Sci Prog 86:77101.

Blomberg SP, Garland TJ, Ives AR (2003) Testing for phylogenetic signal in comparative data: behavioral traits are more labile. Evolution 57:717-745

Bouchet P, Rocroi J-P (2005). Classification and nomenclator of Gas tropod families. Malacologia 47:1-397

Chown SL, Hoffmann AA, Kristensen TN et al (2010) Adapting to climate change: a perspective from evolutionary physiology. Clim Res 43:3-15

15 Costanzo JP, Litzgus JD, Iverson JB et al (1998) Soil hydric characteristics and environmental ice nuclei influence in supercooling capacity of hatchling painted turtles Chrysemys picta. J Exp Biol 201:3105-3112

Costanzo JP, Moore JB, Lee RE et al (1997) Influence of soil hydric parameters on the winter cold hardiness of a burrowing beetle, Leptinotarsa decemlineata (Say). J Comp Physiol B 167:169-176

Cruz FB, Antenucci D, Luna F et al(2011) Energetics and Liolaemini lizards: implications of a small body size and ecological conservatism. J Comp Physiol B 181:373-382 
David JF, Vannier G (1996) Changes in supercooling with body size, sex and season in the long-lived millipede Polyzonium germanicum (Diplopoda, Polzoniidae). J Zool Lond 240:599-608

Dayrat B, Tillier A, Lecointre G et al (2001) New clades of euthyneuran Gastropods (Mollusca) from 28S rRNA sequences. Mol Phyl Evol 19:225-235

Drummond AJ, Rambaut A (2007) BEAST: Bayesian evolutionary analysis by sampling trees. BMC Evol Biol 7:214

Estoup A, Largiadèr CR, Perrot E et al (1996) Rapid one-tube DNA extraction for reliable PCR detection of fish polymorphic markers and trans genes. Mol Mar Biol Biotechnol 5:295-298

Folmer O, Black M, Hoeh W et al (1994) DNA primers for amplification of mitochondrial cytochrome c oxydase subunit I from diverse metazoan invertebrates. Mol Mar Biol Biotechnol 3:294-297

10 Freckleton RP (2009) The seven deadly sins of comparative analysis. J Evol Biol 22:13671375

Freckleton RP, Harvey PH, Pagel M (2002) Phylogenetic analysis and comparative data: a test and review of evidence. Am Nat 160:712-726

Gargominy O, Neubert E (2011) Identifier les Clausilies de France. MalaCo HS1:109-122.

15 Gargominy O, Ripken TEJ (2011) Une collection de référence pour la malacofaune terrestre de France. MalaCo HS 1:1-108.

Goodfriend GA (1983) Clinal variation and natural selection in the land snail Pleurodonte lucerna in western St. Ann Parish, Jamaica. PhD Dissertation, University of Florida 
Goodfriend GA (1986). Variation in land-snail shell form and size and its causes: a review. Syst Zool $35: 204-223$

Grafen A (1989) The phylogenetic regression. Phil Trans R Soc Lond B 326:119-157

Grenot CJ, Garcin L, Dao J et al (2000) How does the european common lizard, Lacerta vivipara, survive the cold of winter. Comp Biochem Physiol A 127:71-80

Groenenberg DSJ, Neubert E, Gittenberger E (2011) Reappraisal of the "Molecular phylogeny of Western Palaearctic Helicidae s.l. (Gastropoda: Stylommatophora)": when poor science meets GenBank. Mol Phylogenet Evol 61:914-923

Guiller A, Coutellec M-A, Madec L et al (2001) Evolutionary history of the land snail Helix aspersa in western Mediterranean: preliminary results inferred from mitochondrial DNA sequences. Mol Ecol 10:81-87

Guindon S, GascuelO (2003) A simple, fast, and accurate algorithm to estimate large phylogenies by maximum likelihood. Syst Biol 52:696-704

Harmon LJ, Weir JT, Brock CD et al (2008. GEIGER: investigating evolutionary radiations. Bioinformatics 24:129-131

Hausdorf B (2003) Latitudinal and altitudinal body size variation among north-west European land snail species. Global Ecol Biogeogr 12:389-394

Jensen D, Overgaard J, Sorensen JG (2007) The influence of de velopmental stage on cold shock resistance and ability to cold-harden in Drosophila melanogaster. J Insect Physiol $53: 179-186$

Jing XH, Kang L (2003) Geographical variation in egg cold hardiness: a study on the adaptation strategies of the migratory locust Locusta migratoria L. Ecol Entomol 28:151-158 
Kellerman V, Loeschke V, Hoffmann AA et al (2012) Phylogenetic constraints in key, functional traits behind species' climate niches: patterns of desiccation and cold resistance across 95 Drosophila species. Evolution 66:3377-3389

Kerney MP, Cameron RAD (1999) Guide des escargots et limaces d'Europe. Delachaux et Niestlé, Lausanne.

Kerney MP, Cameron, RAD, Jungbluth JH (1983) Die Land schnecken Nord- und Mitteleuropas. Parey, Hamburg.

Klamkin MS (1971) Elementary approximations to the area of n-dimensional ellipsoids. Am Math Mon 78:280-283

Klamkin MS (1976) Corrections to "Elementary approximations to the area of n-dimensional ellipsoids". Am Math Mon 83:478

Klein Tank AMG, Wijngaard JB, Können GP et al (2002) Daily dataset of 20th-century surface air temperature and precipitation series for the European Climate Assessment. Int J Clim 22:1441-1453

15 Koene JM, Schulenburg H (2005) Shooting darts: co-evolution and counter-adaptation in hermaphroditic snails. BMC Evol Biol 5:25. doi:10.1186/1471-2148-5-25.

Kosnik ME, Jablonski D, Lockwood R et al (2006) Quantifying molluscan body size in evolutionary and ecological analyses: maximizing the return on data-collection efforts. Palaios 21:588-597

20 Koštál V, Rozsypal J, Pavel P et al (2013) Physiological and biochemical responses to cold and drought in the rock-dwelling pulmonate snail, Chondrina avenacea. J Comp Physiol $\mathrm{B}$ in press. DOI 10.1007/s00360-013-0749-0 
Kukal O, Duman JG (1989) Switch in the overwintering strategy of two insect species and latitudinal differences in cold hardiness. Can J Zool 67:825-827

Lê S, Josse J, Husson F (2008) FactoMineR: an R package for multivariate analysis. J Stat Softw 25:1-18

5 Lee RE, Costanzo JP (1998) Biological ice nucleation and ice distribution in cold-hardy ectothermic animals. Ann Rev Physiol 60:55-72

Machin J (1967) Structural adaptations for reducing water- loss in three species of terrestrial snail. J Zool Lond 152:55-65

MacKenzie AP (1977) Non-equilibrium freezing behaviour of aqueous systems. Philos Trans Roy Soc Lond B 278:167-189

Moine O, Rousseau D-D, Jolly D et al (2002) Paleoclimatic reconstruction using mutual climatic range on terrestrial Mollusks. Quaternary Res 57:162-172

Moran AL (2004) Egg size evolution in tropical American Arcid bivalves: the comparative method and the fossil record. Evolution 58:2718-2733

15 Nicolai A, Filser J, Lenz R et al (2011) Adjustment of metabolite composition in the haemolymph to seasonal variations in the land snail Helix pomatia. J Comp Physiol B $181: 457-466$

Nicolai A, Vernon P, Lee M et al (2005) Supercooling ability in two populations of the land snail Helix pomatia (Gastropoda: Helicidae) and ice-nucleating activity of gut bacteria. Cryobiology 50:48-57

Nunn CL (2011) The comparative approach in evolutionary anthropology and biology. University of Chicago Press, Chicago. 
Nyamukondiwa C, Terblanche JS, Marshall KE et al (2011) Basal cold but not heat tolerance constrains plasticity among Drosophila species (Diptera: Drosophilidae). J Evol Biol $24: 1927-1938$

Nylander JAA (2004) MrAIC.pl. Program distributed by the author. Evol Biol Center, Uppsala University.

Orme CDL, Freckleton RP, Thomas GH et al (2012) CAPER: comparative analyses of phylogenetics and evolution in R. Available from http://cran.rproject.org/web/packages/caper/ (accessed April 2013)

Örstan A (2011) A method to measure snail shell volumes. Triton 23:31-32

Pakay JL, Withers PC, Hobbs AA et al (2002) In vivo downregulation of protein synthesis in the snail Helix aspersa during estivation. Am J Physiol Regul Integr Comp Physiol 283:197-204

Pither J (2003) Climate tolerance and interspecific variation in geographic range size. Proc R Soc Lond B 270:475-481

Powell EN, Stanton RJJ (1985) Estimating biomass and energy flow of molluscs in palaeocommunities. Palaeontology 28:1-34

Ramløv H (2000) Aspects of natural cold tolerance in ectothermic animals. Hum Reprod $15: 24-26$

20 Raup DM, Graus RR (1972) General equations for volume and surface area of a logarithmically coiled shell. Math Geol4:307-316

Revell LJ (2010) Phylogenetic signal and linear regression on species data. Methods Ecol Evol 1:319-329 
Ronquist F, Huelsenbeck J (2003) MrBayes 3: Bayesian phylogenetic inference under mixed models. Bioinformatics 19:1572-1574

Sinclair BJ, Marshall DJ, Singh S et al (2004) Cold tolerance of Littorinidae from southern Africa: intertidal snails are not.constrained to freeze tolerance. J Comp Physiol B $174: 617-624$

Slotsbo S, Hansen LM, Jordaens K et al (2012) Cold tolerance and freeze-induced glucose accumulation in three terrestrial slugs. Comp Biochem Physiol A 161:443-449

Steinke D, Albrecht C, Pfenninger M (2004) Molecular phylogeny and character evolution in the Western Palaearctic Helicidae s.l. (Gastropoda:Stylommatophora). Mol Phylogenet Evol 32:724-734

Storey KB, Storey JM (1990) Metabolic rate depression and biochemical adaptation in anaerobiosis, hibernation and estivation. Quart Rev Biol 65:145-174

Storey KB, Storey JM (2004) Metabolic rate depression in animals: transcriptional and translational controls. Biol Rev 79:207-233

15 Storey KB, Storey JM, Churchill TA (2007) Freezing and anoxia tolerance of slugs: a metabolic perspective. J Comp Physiol B 177:833-840

Strachan LA, Tarnowski-Garner HE, Marshall KE et al (2011) The evolution of cold tolerance in Drosophila larvae. Physiol Biochem Zool 84:43-53

Vernon P, Vannier G, Luce JM (1997) Diminution de la capacité de surfusion au cours de l'embryogenèse et du développement larvaire chez un coléoptère. C R Acad Sci $320: 359-366$

Voituron Y, Barré H, Ramlov H et al (2009) Freeze tolerance evolution among anurans: frequency and time of appearance. Cryobiology 58:241-247 
Wade CM, Mordan PB, Clarke B (2001) A phylogeny of the land snails (Gastropoda:

Pulmonata). Proc R Soc Lond B 268:413-422

Wilson PW, Heneghan AF, Haymet ADJ (2003) Ice nucleation in nature: supercooling points (SCP) measurements and the role of heterogeneous nucleation. Cryobiology 46:88-98

5 Zachariassen KE, Kristiansen E (2000) Ice nucleation and antinucleation in nature.

Cryobiology $41: 257-279$

Zachariassen KE, Kristiansen E, Pedersen SA et al(2004) Ice nucleation in solutions and freeze-avoiding insects - homogeneous or heterogeneous? Cryobiology 48:309-321 


\section{Figure captions}

Figure 1. Distribution area covered by the Kerney et al (1983) and Kerney and Cameron (1999) guides. Collection sites (number from 1 to 6 ) of the land snail species are indicated with reference to

5 Table 1. 1: Marais Poitevin; 2: Mercantour; 3: Bretagne; 4: Rhine Valley; 5: Pyrénées; 6: Corse (modified from Kerney et al 1983)

Figure 2. Species factorial scores on the first two Principal Component Analysis axes with inset showing the plot of the 'environmental' (10 climatic and 6 geographic variables) vectors on the same 10 plane.

Figure 3. Fifty percent majority-rule consensus phylogram from the $\mathrm{BI}$ analysis of $28 \mathrm{~S}$ and $\mathrm{COI}$ sequences of 31 land snail species. The tree is rooted using Gibbula umbilicalis as outgroup. Branches without posterior probability values (values in italics) are supported by less than $50 \%$ of the sampled trees. 28S and COI GenB ank accession numbers are given in Table 2. Scaled photographs of the species shells are presented.

Figure 4. Correlation between residual water content (WCres) and mean $\mathrm{SV}_{\text {corr }}$ in 31 land snail species. Dotted line: cross-species correlation; black line: correlation corrected for phylogeny. Shell form : $+=$ globular, $\triangle$ =depressed, $\times=$ oblong, $O=$ conical.

Figure 5. Temperature of crystallisation (Tc) as a function of the log of water mass (logWM) and the residual water content $\left(\mathrm{WC}_{\text {res }}\right)$ in land snails. 
Table 1

Position in the Gastropod classification (following Bouchet and Rocroi, 2005) of the 31 north -west European land snail species studied. The code used in subsequent figures for each species is indicated, as well as the collection site with referenc e to Fig. 1, and general distribution (Kerney et al., 1983; Kerney and Cameron, 1999).

\begin{tabular}{|c|c|c|c|c|c|c|c|}
\hline Clade & Super-family & Family & Sub-family & Species & Code & $\begin{array}{l}\text { Collection } \\
\text { site }\end{array}$ & Distribution \\
\hline \multicolumn{8}{|c|}{ CAENOGASTROPODA } \\
\hline \multicolumn{7}{|c|}{$\begin{array}{l}\text { HETEROBRANCHIA } \\
\text { STYLOMMATOPHORA }\end{array}$} & Mediterranean and Western Europe \\
\hline \multicolumn{8}{|c|}{ ORTHURETHRA } \\
\hline & COCHLICOPIDEA & Cochlicopidae & & Cochlicopa Iubrica & $\mathrm{Cl}$ & 2 & Holarctic \\
\hline \multirow{5}{*}{\multicolumn{2}{|c|}{ PUPILLOIDEA }} & Pupillidae & & $\begin{array}{l}\text { Pupilla muscorum } \\
\text { Pupilla alpicola }\end{array}$ & $\begin{array}{l}\mathrm{Pm} \\
\mathrm{Pa}\end{array}$ & $\begin{array}{l}1 \\
2\end{array}$ & $\begin{array}{l}\text { Holarctic } \\
\text { Alps }\end{array}$ \\
\hline & & Chondrinidae & & Abida secale & As & 2 & Western Europe and Alps \\
\hline & & Valloniidae & & Vallonia costata & Vc & 2 & Holarctic \\
\hline & & Vertiginidae & & Columella columella & Col & 2 & Arctic and Alps \\
\hline & & & & Columella edentula & $\mathrm{Ce}$ & 2 & Palearctic \\
\hline \multirow{2}{*}{\multicolumn{2}{|c|}{ ENOIDEA }} & Enidae & & Ena montana & $\mathrm{Em}$ & 2 & Central Europe and Alps \\
\hline & & & & Zebrina detrita & $\mathrm{Zd}$ & 2 & Southern Europe \\
\hline \multicolumn{8}{|c|}{ SIGMURETHRA } \\
\hline \multirow{2}{*}{\multicolumn{2}{|c|}{ CLAUSILIOIDEA }} & Clausiliidae & & Macrogastra attenuata & $\mathrm{Ma}$ & 2 & Central and Western Europe, Alps \\
\hline & & & & Clausilia bidentata & $\mathrm{Cb}$ & 1 & Northern and Western Europe \\
\hline & PUNCTOIDEA & Discidae & & Discus rotundatus & $\mathrm{Dr}$ & 3 & Central and Western Europe \\
\hline \multirow{2}{*}{\multicolumn{2}{|c|}{ GASTRODONTOIDEA }} & Oxychilidae & & Oxychilus draparnaudi & Od & 3 & Mediterranean and Western Europe \\
\hline & & & & Nesovitrea hammonis & $\mathrm{Nh}$ & 2 & Holarctic \\
\hline \multirow{16}{*}{\multicolumn{2}{|c|}{ HELICOIDEA }} & Helicidae & Helicinae & Helix pomatia & $\mathrm{Hp}$ & 4 & Central and Southern Europe \\
\hline & & & & Helix lucorum & $\mathrm{HI}$ & 5 & Mediterranean and Central Europe \\
\hline & & & & Cornu aspersum & Cas & 3 & Mediterranean and Western Europe \\
\hline & & & & Cantareus apertus & $\mathrm{Ca}$ & 6 & Mediterranean \\
\hline & & & & Cepaea nemoralis & $\mathrm{Cn}$ & 1 & Western Europe \\
\hline & & & & Cepaea hortensis & $\mathrm{Ch}$ & 3 & Central and Western Europe \\
\hline & & & & Cepaea sylvatica & Cs & 2 & Alps \\
\hline & & & & Eobania vermiculata & Ev & 6 & Mediterranean \\
\hline & & & & Theb a pisana & $\mathrm{Tp}$ & 1 & Mediterranean and Atlantic \\
\hline & & & Ariantinae & Arianta arbustorum & $\mathrm{Aa}$ & 2 & Central and Western Europe \\
\hline & & & & Helicigona lapicida & $\mathrm{Hla}$ & 5 & Central and Western Europe \\
\hline & & Cochlicellidae & & Cochlicella acuta & Co & 1 & Mediterranean and Atlantic \\
\hline & & Hygromiidae & Hygromiinae & Hygromia limbata & Hli & 5 & South-Western Europe \\
\hline & & & & Trochulus hispidus & Th & 2 & Europe \\
\hline & & & Ciliellinae & Ciliella ciliata & $\mathrm{Cc}$ & 2 & Alps \\
\hline & & & Geomitrinae & Candidula unifasciata & $\mathrm{Cu}$ & 2 & Central Europe \\
\hline
\end{tabular}




\section{Table 2}

Means and standard errors of fresh mass (FM), water mass (WM), water content (WC), temperature of crystallisation (Tc) and corrected surface-volume ratio ( $\left.\mathrm{SV}_{\text {corr }}\right)$ of the 31 land snail species ranged by increasing mass. For $\mathrm{SV}_{\text {corr }}, n$ is comprised between 5 and 10 ; the general shell form, as defined by Falkner et al. (2002) is given: $\mathrm{C}=$ conical, $\mathrm{D}=$ depressed, $\mathrm{O}=$ oblong, $\mathrm{G}=$ globular. GenBank accession numbers are indicated. * Sequence imported from GenBank.

\begin{tabular}{|c|c|c|c|c|c|c|c|c|}
\hline Species & $n$ & $\begin{array}{l}\text { FM } \\
(\mathrm{mg})\end{array}$ & $\begin{array}{l}\text { WM } \\
(\mathrm{mg})\end{array}$ & $\begin{array}{c}\mathrm{WC} \\
\left(\mathrm{gH}_{2} \mathrm{O} \cdot \mathrm{gFM}^{-1}\right)\end{array}$ & $\begin{array}{l}\text { Tc } \\
\left({ }^{\circ} \mathrm{C}\right)\end{array}$ & $\mathrm{SV}_{\text {corr }}$ & $\begin{array}{c}\text { Genbank } \\
\text { Acc. Nos. } \\
28 S\end{array}$ & $\begin{array}{c}\text { Genbank } \\
\text { Acc. Nos. } \\
\text { COI }\end{array}$ \\
\hline Columella edentula & (9) & $\begin{array}{l}1.36 \\
0.39\end{array}$ & $\begin{array}{l}0.64 \\
0.24\end{array}$ & $\begin{array}{l}50.22 \\
12.87\end{array}$ & $\begin{array}{c}-16.81 \\
1.89\end{array}$ & $\begin{array}{c}7.94 \\
C\end{array}$ & JX911259 & JX911290 \\
\hline Columella columella & (20) & $\begin{array}{l}2.33 \\
0.55\end{array}$ & $\begin{array}{l}1.08 \\
0.31\end{array}$ & $\begin{array}{c}42.09 \\
7.98\end{array}$ & $\begin{array}{c}-13.82 \\
2.18\end{array}$ & $\begin{array}{c}8.60 \\
C\end{array}$ & JX911264 & JX911295 \\
\hline Vallonia costata & $(21)$ & $\begin{array}{l}2.42 \\
0.21\end{array}$ & $\begin{array}{l}1.13 \\
0.17\end{array}$ & $\begin{array}{r}46.77 \\
4.91\end{array}$ & $\begin{array}{c}-15.69 \\
1.11\end{array}$ & $\begin{array}{c}9.29 \\
D\end{array}$ & JX911281 & JX911312 \\
\hline Pupilla muscorum & (25) & $\begin{array}{l}5.50 \\
1.01\end{array}$ & $\begin{array}{l}2.67 \\
0.67\end{array}$ & $\begin{array}{c}44.04 \\
6.71\end{array}$ & $\begin{array}{c}-14.81 \\
2.09\end{array}$ & $\begin{array}{c}7.75 \\
\text { C }\end{array}$ & JX911278 & JX911309 \\
\hline Pupilla alpicola & (24) & $\begin{array}{l}5.91 \\
0.96\end{array}$ & $\begin{array}{l}2.85 \\
0.50\end{array}$ & $\begin{array}{c}46.13 \\
5.96\end{array}$ & $\begin{array}{c}-15.18 \\
1.98\end{array}$ & $\begin{array}{l}7.42 \\
\mathrm{C}\end{array}$ & JX911276 & JX911307 \\
\hline Nesovitrea hammonis & (8) & $\begin{array}{c}11.05 \\
1.13\end{array}$ & $\begin{array}{l}5.44 \\
0.85\end{array}$ & $\begin{array}{c}49.07 \\
4.34\end{array}$ & $\begin{array}{l}-8.73 \\
1.56\end{array}$ & $\begin{array}{c}8.60 \\
D\end{array}$ & JX911277 & JX911308 \\
\hline Cochlicopa Iubrica & (26) & $\begin{array}{l}14.95 \\
2.72\end{array}$ & $\begin{array}{l}8.08 \\
1.97\end{array}$ & $\begin{array}{c}55.43 \\
6.64\end{array}$ & $\begin{array}{c}-14.02 \\
1.72\end{array}$ & $\begin{array}{c}8.30 \\
0\end{array}$ & JX911261 & JX911292 \\
\hline Abida secale & (14) & $\begin{array}{c}20.72 \\
1.74\end{array}$ & $\begin{array}{l}8.26 \\
1.76\end{array}$ & $\begin{array}{c}38.96 \\
7.91\end{array}$ & $\begin{array}{c}-14.36 \\
2.46\end{array}$ & $\begin{array}{c}9.02 \\
0\end{array}$ & JX911254 & JX911285 \\
\hline Candidula unifasciata & (9) & $\begin{array}{l}31.70 \\
13.09\end{array}$ & $\begin{array}{c}16.27 \\
7.52\end{array}$ & $\begin{array}{c}50.18 \\
6.42\end{array}$ & $\begin{array}{c}-14.02 \\
1.66\end{array}$ & $\begin{array}{c}7.85 \\
G\end{array}$ & JX911266 & JX911297 \\
\hline Clausilia bidentata & $(17)$ & $\begin{array}{c}39.50 \\
6.69\end{array}$ & $\begin{array}{c}10.86 \\
2.02\end{array}$ & $\begin{array}{c}28.45 \\
7.85\end{array}$ & $\begin{array}{c}-16.14 \\
1.14\end{array}$ & $\begin{array}{c}11.0 \\
0\end{array}$ & JX911257 & JX911288 \\
\hline Discus rotundatus & (29) & $\begin{array}{c}64.62 \\
8.29\end{array}$ & $\begin{array}{c}27.37 \\
4.49\end{array}$ & $\begin{array}{c}42.03 \\
4.12\end{array}$ & $\begin{array}{c}-14.16 \\
1.63\end{array}$ & $\begin{array}{c}9.06 \\
D\end{array}$ & JX911267 & JX911298 \\
\hline Trochulus hispidus & (7) & $\begin{array}{l}69.88 \\
15.55\end{array}$ & $\begin{array}{l}43.21 \\
11.03\end{array}$ & $\begin{array}{l}49.77 \\
10.33\end{array}$ & $\begin{array}{c}-12.11 \\
1.69\end{array}$ & $\underset{D}{8.15}$ & JX911279 & JX911310 \\
\hline Macrogastra attenuata & $(30)$ & $\begin{array}{l}78.99 \\
8.55\end{array}$ & $\begin{array}{c}30.14 \\
5.42\end{array}$ & $\begin{array}{c}35.82 \\
6.4\end{array}$ & $\begin{array}{c}-14.60 \\
0.89\end{array}$ & $\begin{array}{c}10.58 \\
0\end{array}$ & JX911274 & JX911305 \\
\hline Ciliella ciliata & (11) & $\begin{array}{l}99.64 \\
24.56\end{array}$ & $\begin{array}{l}59.18 \\
15.16\end{array}$ & $\begin{array}{c}59.12 \\
2.83\end{array}$ & $\begin{array}{c}-6.84 \\
1.40\end{array}$ & $\begin{array}{c}8.12 \\
D\end{array}$ & JX911258 & JX911289 \\
\hline Cochlicella acuta & (18) & $\begin{array}{c}102.98 \\
14.61\end{array}$ & $\begin{array}{l}49.62 \\
13.85\end{array}$ & $\begin{array}{c}47.42 \\
8.13\end{array}$ & $\begin{array}{c}-10.46 \\
2.15\end{array}$ & $\begin{array}{c}9.04 \\
0\end{array}$ & JX911263 & JX911294 \\
\hline Ena montana & (29) & $\begin{array}{c}202.87 \\
36.68\end{array}$ & $\begin{array}{c}103.14 \\
27.70\end{array}$ & $\begin{array}{c}48.88 \\
6.12\end{array}$ & $\begin{array}{l}-8.37 \\
2.26\end{array}$ & $\begin{array}{c}8.38 \\
0\end{array}$ & JX911268 & JX911299 \\
\hline Pomatias elegans & (29) & $\begin{array}{c}359.15 \\
69.90\end{array}$ & $\begin{array}{c}168.24 \\
33.57\end{array}$ & $\begin{array}{c}47.09 \\
5.37\end{array}$ & $\begin{array}{l}-5.53 \\
0.66\end{array}$ & $\begin{array}{c}7.48 \\
G\end{array}$ & AY01416161* & JX911283 \\
\hline Oxychilus draparnaudi & (10) & $\begin{array}{c}378.14 \\
82.18\end{array}$ & $\begin{array}{c}230.32 \\
49.15\end{array}$ & $\begin{array}{c}61.15 \\
4.34\end{array}$ & $\begin{array}{l}-5.21 \\
0.92\end{array}$ & $\begin{array}{c}8.85 \\
D\end{array}$ & JX911275 & JX911306 \\
\hline Hygromia limbata & (8) & $\begin{array}{l}579.59 \\
158.92\end{array}$ & $\begin{array}{l}320.75 \\
109.72\end{array}$ & $\begin{array}{c}54.42 \\
7.85\end{array}$ & $\begin{array}{l}-6.98 \\
1.35\end{array}$ & $\begin{array}{c}7.69 \\
G\end{array}$ & JX911272 & JX911303 \\
\hline Zebrina detrita & $(22)$ & $\begin{array}{l}606.24 \\
139.11\end{array}$ & $\begin{array}{l}335.97 \\
135.85\end{array}$ & $\begin{array}{l}52.43 \\
16.72\end{array}$ & $\begin{array}{l}-10.55 \\
1.92\end{array}$ & $\begin{array}{c}8.28 \\
0\end{array}$ & JX911282 & JX911313 \\
\hline Helicigona lapicida & (17) & $\begin{array}{c}651.42 \\
80.22\end{array}$ & $\begin{array}{l}306.19 \\
61.57\end{array}$ & $\begin{array}{l}47.05 \\
7.46\end{array}$ & $\begin{array}{l}-14.57 \\
2.45\end{array}$ & $\begin{array}{c}9.46 \\
D\end{array}$ & JX911270 & JX911301 \\
\hline Theba pisana & $(30)$ & $\begin{array}{l}998.23 \\
185.44\end{array}$ & $\begin{array}{l}628.73 \\
156.30\end{array}$ & $\begin{array}{c}62.39 \\
7.39\end{array}$ & $\begin{array}{l}-7.27 \\
1.84\end{array}$ & $\begin{array}{l}7.57 \\
G\end{array}$ & JX911280 & JX911311 \\
\hline Arianta arb ustorum & (15) & $\begin{array}{c}1666.33 \\
435.94\end{array}$ & $\begin{array}{l}867.73 \\
297.65\end{array}$ & $\begin{array}{c}51.08 \\
8.35\end{array}$ & $\begin{array}{l}-14.59 \\
1.55\end{array}$ & $\begin{array}{l}7.75 \\
G\end{array}$ & JX911253 & JX911284 \\
\hline Cepaea hortensis & (30) & $\begin{array}{c}1796.15 \\
267.01\end{array}$ & $\begin{array}{c}1086.70 \\
212.74\end{array}$ & $\begin{array}{c}60.08 \\
6.50\end{array}$ & $\begin{array}{l}-8.44 \\
2.26\end{array}$ & $\begin{array}{c}7.60 \\
G\end{array}$ & JX911260 & JX911291 \\
\hline Cepaea sylvatica & (12) & $\begin{array}{c}2055.50 \\
324.93\end{array}$ & $\begin{array}{c}1156.17 \\
195.01\end{array}$ & $\begin{array}{c}56.39 \\
4.78\end{array}$ & $\begin{array}{c}-11.88 \\
2.26\end{array}$ & $\begin{array}{c}7.71 \\
G\end{array}$ & JX911265 & JX911296 \\
\hline Cantareus apertus & (5) & $\begin{array}{c}2819.40 \\
235.77\end{array}$ & $\begin{array}{c}1938.00 \\
150.01\end{array}$ & $\begin{array}{c}68.77 \\
1.17\end{array}$ & $\begin{array}{l}-5.72 \\
0.54\end{array}$ & $\begin{array}{l}7.79 \\
G\end{array}$ & JX911255 & JX911286 \\
\hline Cepaea nemoralis & (20) & $\begin{array}{c}3052.85 \\
689.98\end{array}$ & $\begin{array}{c}1694.70 \\
392.20\end{array}$ & $\begin{array}{c}55.69 \\
5.56\end{array}$ & $\begin{array}{c}-10.21 \\
1.79\end{array}$ & $\begin{array}{c}7.71 \\
G\end{array}$ & JX911262 & JX911293 \\
\hline Eobania vermiculata & $(8)$ & $\begin{array}{c}4205.25 \\
646.64\end{array}$ & $\begin{array}{c}2251.25 \\
338.07\end{array}$ & $\begin{array}{c}53.73 \\
4.62\end{array}$ & $\begin{array}{c}-7.86 \\
0.51\end{array}$ & $\begin{array}{c}7.89 \\
G\end{array}$ & JX911269 & JX911300 \\
\hline Cornu aspersum & (30) & $\begin{array}{l}4549.18 \\
1374.59\end{array}$ & $\begin{array}{c}2966.01 \\
967.29\end{array}$ & $\begin{array}{c}64.90 \\
5.35\end{array}$ & $\begin{array}{c}-5.42 \\
1.97\end{array}$ & $\begin{array}{c}7.63 \\
G\end{array}$ & JX911256 & JX911287 \\
\hline Helix pomatia & (30) & $\begin{array}{c}18406.17 \\
2605.40\end{array}$ & $\begin{array}{c}11885.35 \\
1824.61\end{array}$ & $\begin{array}{c}64.28 \\
3.59\end{array}$ & $\begin{array}{l}-6.17 \\
2.86\end{array}$ & $\begin{array}{c}7.48 \\
G\end{array}$ & JX911273 & JX911304 \\
\hline Helix Iucorum & (13) & $\begin{array}{c}34069.78 \\
4556.17\end{array}$ & $\begin{array}{c}17546.44 \\
3602.08\end{array}$ & $\begin{array}{c}51.34 \\
5.6\end{array}$ & $\begin{array}{l}-4.45 \\
2.07\end{array}$ & $\begin{array}{c}7.81 \\
G\end{array}$ & JX911271 & JX911302 \\
\hline
\end{tabular}




\section{Table 3}

Matrix of phylogenetic correlations between explicative variables. The correlation coefficients $r$ are indicated above diagonal, $p$ values are indicated below it. Taking into account Bonferroni correction, significativity is considered for $p<0.0083$. Df $=29$.

\begin{tabular}{ccccc}
\hline & WC $_{\text {res }}$ & $\log W M$ & $\mathbf{S V}_{\text {corr }}$ & ENV \\
\hline WC $_{\text {res }}$ & - & 0.0 & $\mathbf{0 . 5 4}$ & 0.0 \\
LogWM & $N S$ & - & 0.0 & 0.36 \\
$\mathbf{S V}_{\text {corr }}$ & $\mathbf{0 . 0 0 1}$ & $N S$ & - & 0.0 \\
ENV & $N S$ & $N S$ & $N S$ & - \\
\hline
\end{tabular}




\section{Table 4}

Best-supported models (total weight $=93.7 \%$ ) for predicting Tc in land snails ( $n=31$ species). LL: log likelihood of the model, AICc: Akaike's Information Criterion corrected for the number of parameters in the model, $\triangle \mathrm{AICc}$ : difference in AICc between a model and the best-fitting one, $\lambda$ : Pagel's maximum likelihood, S.E.: Standard Error of the estimated coefficient for each predictor.

\begin{tabular}{|c|c|c|c|c|c|c|c|c|c|c|}
\hline & $r^{2}$ adj & LL & AlCc & $\triangle \mathrm{AICc}$ & $\lambda$ & predictors & estim. coeff. & S.E. & $p$ & weight (\%) \\
\hline & & & & & & (intercept) & -12.48 & 2.16 & $<0.001$ & \\
\hline \multirow[t]{3}{*}{$T c \sim \log W M+W C_{r e s}+E N V$} & 0.599 & -69.12 & 147.12 & 0 & 0.797 & $\log W M$ & 2.37 & 0.52 & $<0.001$ & 37.3 \\
\hline & & & & & & $\mathbf{W C}_{\text {res }}$ & 0.19 & 0.06 & $<0.01$ & \\
\hline & & & & & & (intercept) & -13.00 & 2.32 & $<0.001$ & \\
\hline \multirow[t]{3}{*}{$T c \sim \log W M+W C_{r e s}$} & 0.574 & -70.43 & 147.29 & 0.17 & 0.839 & $\log W M$ & 2.80 & 0.47 & $<0.001$ & 34.3 \\
\hline & & & & & & $\mathbf{W} \mathbf{C}_{\text {res }}$ & 0.19 & 0.06 & $<0.01$ & \\
\hline & & & & & & (intercept) & -15.65 & 6.27 & $<0.05$ & \\
\hline \multirow[t]{3}{*}{$\mathrm{Tc} \sim \log \mathrm{WM}+\mathrm{WC}_{\mathrm{res}}+\mathrm{SV}_{\mathrm{corr}}$} & 0.561 & -70.31 & 149.52 & 2.40 & 0.844 & $\log W M$ & 2.88 & 0.51 & $<0.001$ & 11.3 \\
\hline & & & & & & $\mathbf{W} \mathbf{C}_{\text {res }}$ & 0.21 & 0.08 & $<0.05$ & \\
\hline & & & & & & (intercept) & -14.59 & 6.13 & $<0.05$ & \\
\hline \multirow{2}{*}{$\mathrm{Tc} \sim \log \mathrm{WM}+\mathrm{WC}_{\mathrm{res}}+\mathrm{SV}_{\mathrm{corr}}+\mathrm{ENV}$} & 0.585 & -69.03 & 149.61 & 2.49 & 0.801 & $\log W M$ & 2.44 & 0.55 & $<0.001$ & 10.8 \\
\hline & & & & & & $\mathbf{W} \mathbf{C}_{\text {res }}$ & 0.21 & 0.08 & $<0.05$ & \\
\hline
\end{tabular}


Figure 1

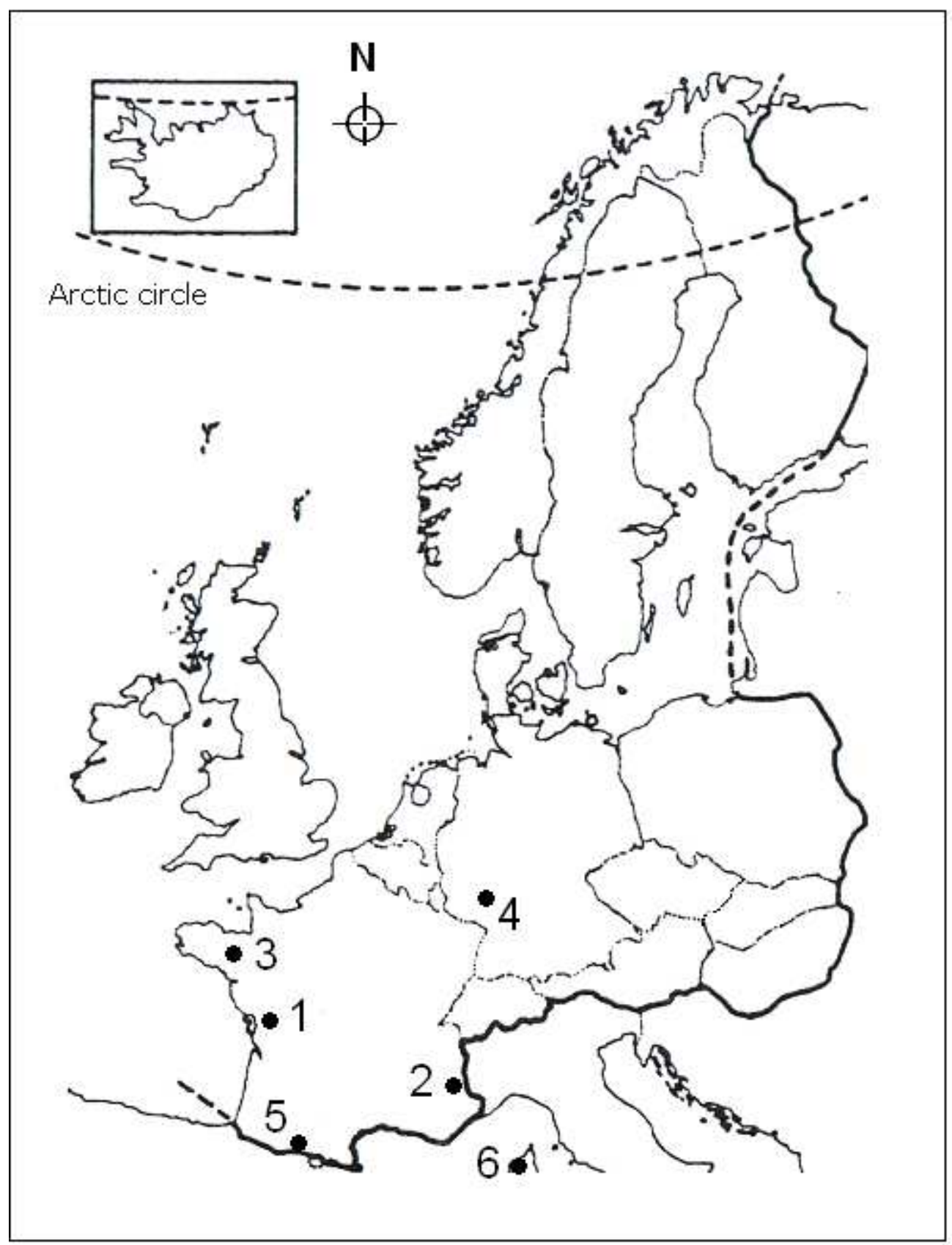




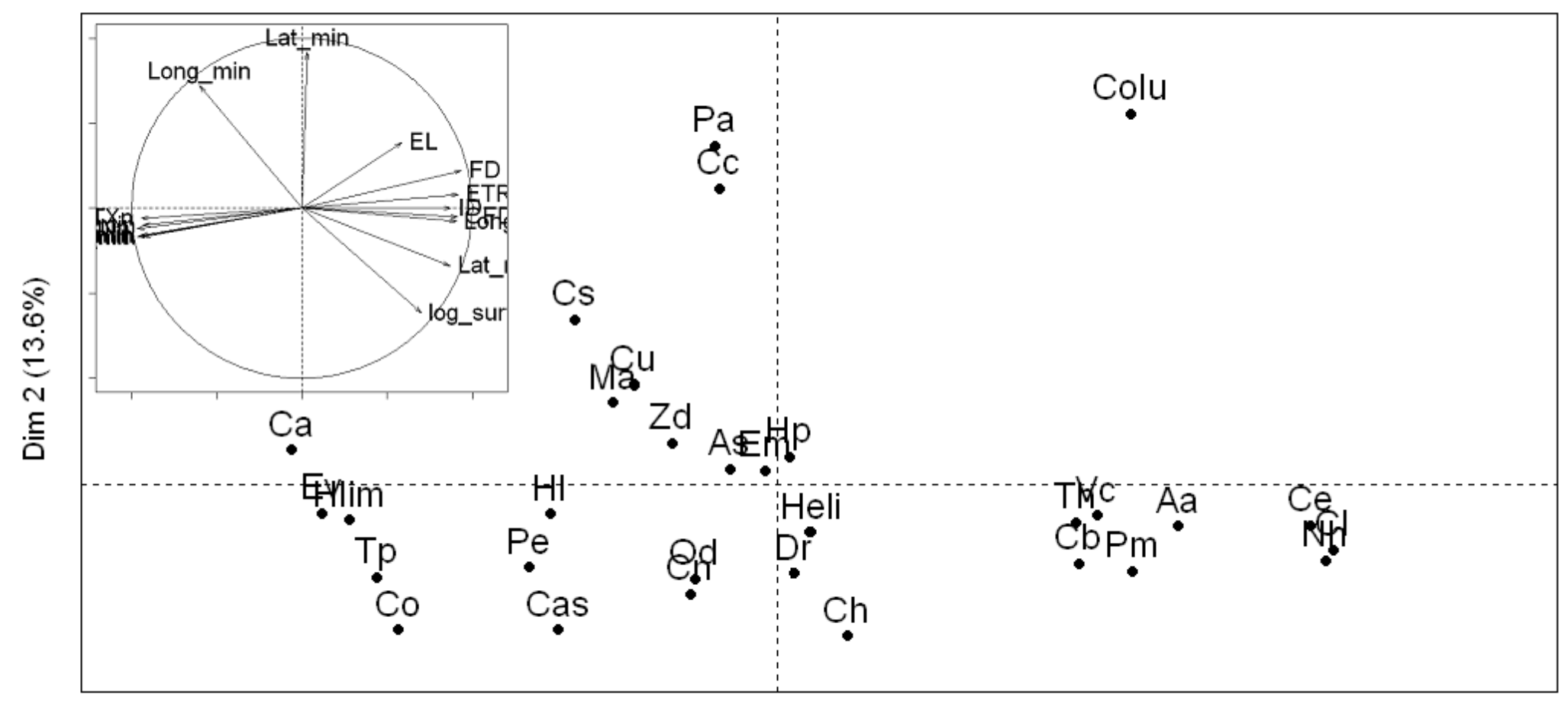

$\operatorname{Dim} 1(71.9 \%)$ 
Figure 3

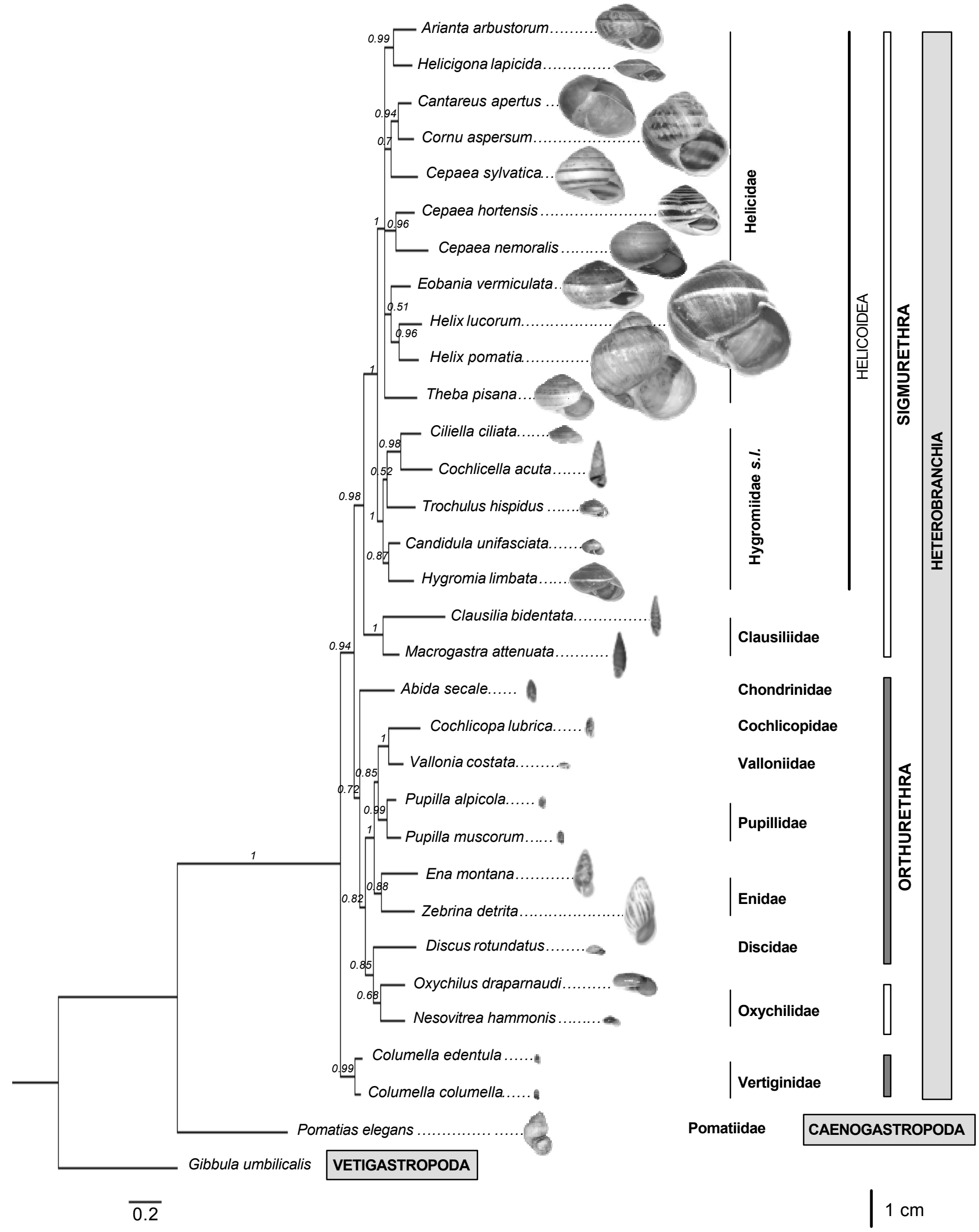


Ans art, Guiller, Moine, Martin and Madec-Cold hardiness is size-constraned in land snails

Figure 4

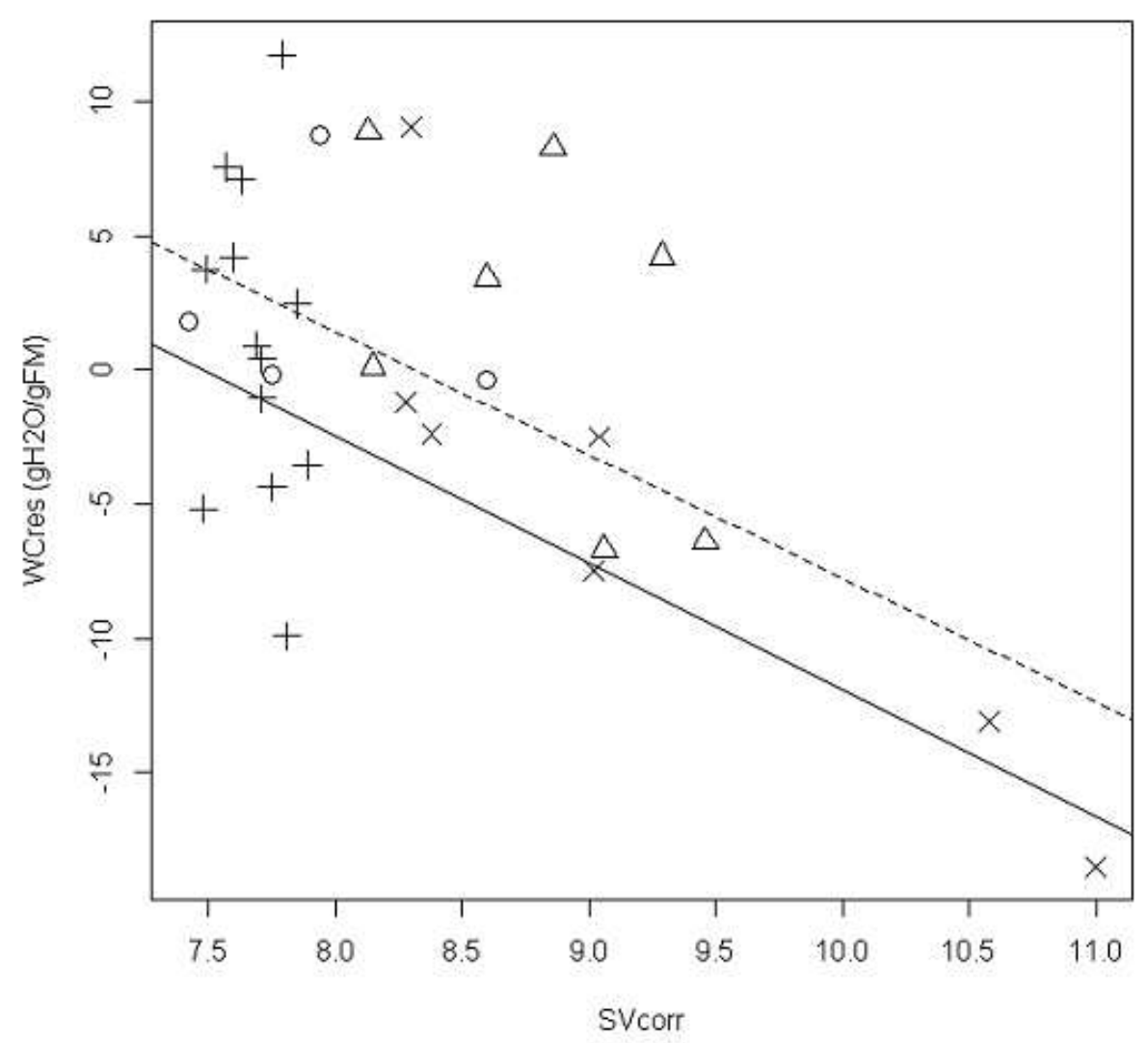


Figure 5

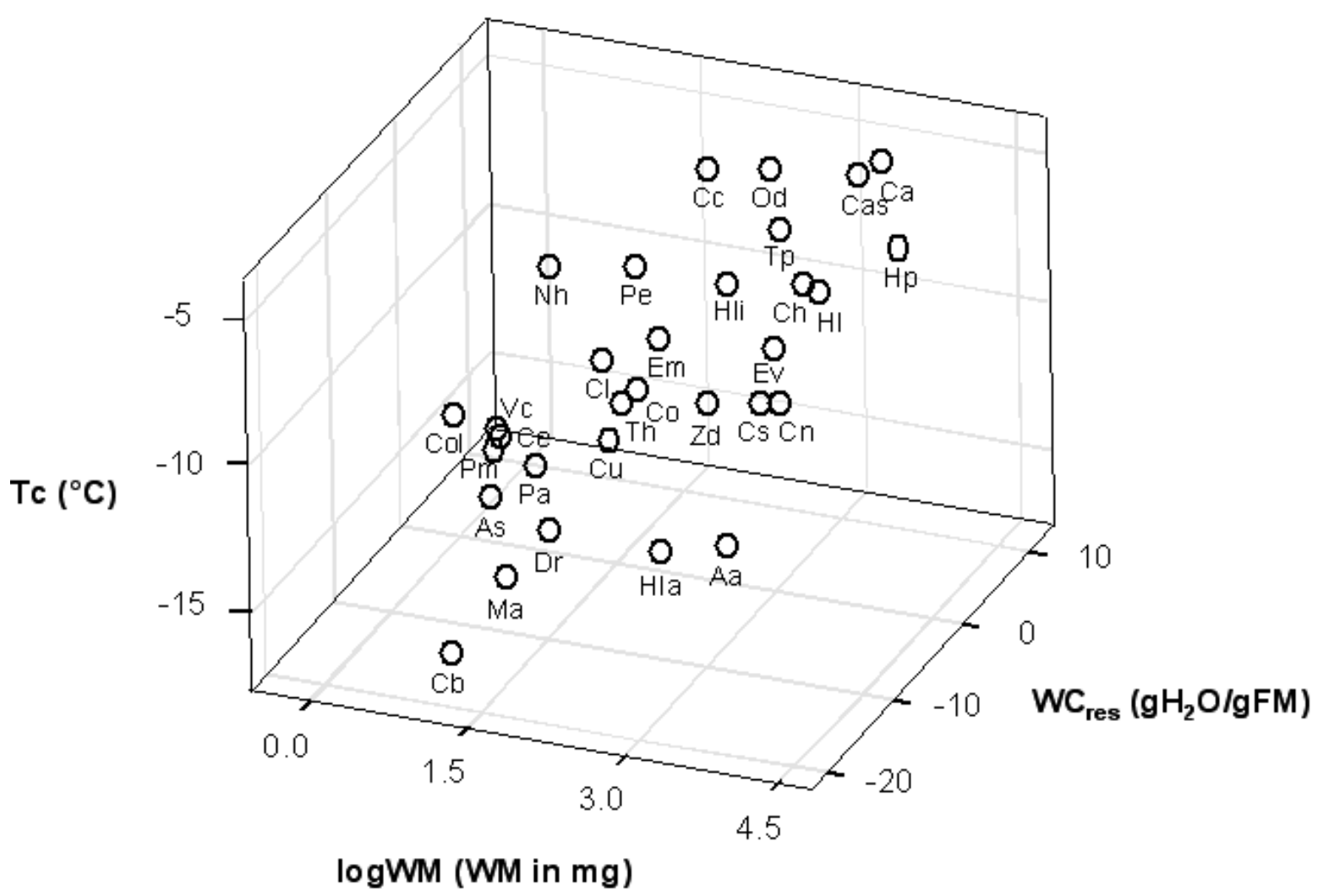

